\title{
Sistem Pendukung Keputusan Menentukan Prioritas Tujuan Wisata Daerah pada Kabupaten Karo dengan Metode TOPSIS
}

\author{
Jimmi Herdianda Gurusinga ${ }^{1}$, Bosker Sinaga ${ }^{2}$, Anita Sindar $^{3}$ \\ 1,2,3 Teknik Informatika, STMIK Pelita Nusantara, Jl. Iskandar Muda No. 1 Medan, Indonesia \\ e-mail: ${ }^{1}$ jimmiherdiandagurusinga@gmail.com, ${ }^{2}$ boskersinaga@gmail.com, ${ }^{3}$ haito_ita@yahoo.com \\ Submitted Date: August $30^{\text {th }}, 2020$ \\ Revised Date: September 23 $3^{\text {rd }}, 2020$ \\ Reviewed Date: September $22^{\text {nd }}, 2020$ \\ Accepted Date: September $30^{\text {th }}, 2020$
}

\begin{abstract}
There are approximately 20 tourist objects in the Karo Regency area that are close to each other, such as Gundaling Hill, Lumbini Nature Park, Fun Land Mickey Holiday and other places. The main problem is designing a system using the SPK in determining the priority of regional tourist destinations in Karo Regency using the TOPSIS method. Problem solving steps are carried out from problem identification, determining alternative solutions to problems that arise so that the best decisions can be made. The weight of the criteria to determine the preferred criteria. The greater the weight, the more priority. Weights for each criteria for determining priority destination of tourist attractions, Distance from Berastagi (weight 30\%), Facilities and Facilities (weight 15\%), Access (15\%), Type of Tourism (weight 20\%), Entrance Fee (Weight 15\%), Culinary (weight 5\%), and internet network (5\%). The preference value $(V)$ produces alternatives that are ordered from largest to smallest. The biggest preference is tourism priority, in this case Kubu Berastagi Hill becomes a priority destination based on criteria.
\end{abstract}

Keywords: Tourism Priority; Weight; Criteria; SPK; Topsis

\begin{abstract}
Abstrak
Objek wisata di Daerah Kabupaten Karo sejumlah kurang lebih 20 objek wisata yang saling berdekatan seperti Bukit Gundaling, Taman Alam Lumbini, Fun Land Mickey Holiday dan tempat lainnya. Pokok permasalahan yaitu merancang sistem dengan menggunakan SPK dalam menentukan prioritas tujuan wisatawan daerah Pada Kabupaten Karo dengan metode TOPSIS. Langkah penyelesaian permasalahan dilakukan dari identifikasi masalah, menentukan alternatif solusi terhadap permsalahan yang muncul hingga dapat diambil keputusan yang terbaik. Bobot kriteria untuk menentukan kriteria yang lebih diutamakan. Semakin besar bobot, maka semakin diutamakan. Bobot untuk setiap kriteria penentuan prioritas tujuan tempat wisata, Jarak dari Berastagi (bobot 30\%), Sarana dan Fasilitas (bobot 15\%), Akses (15\%), Jenis Wisata (Bobot 20\%), Biaya Masuk (Bobot 15\%), Kuliner (bobot 5\%), dan Jaringan internet (5\%). Nilai preferensi (V) menghasilkan alternatif yang diurutkan dari terbesar sampai terkecil. Preferensi terbesar merupakan prioritas wisata, dalam kasus ini Bukit Kubu Berastagi menjadi prioritas tujuan berdasarkan kriteria.
\end{abstract}

Kata Kunci: Prioritas Wisata; Bobot; Kriteria; SPK; Topsis

\section{Pendahuluan}

Kabupaten Karo terletak di Provinsi Sumatra Utara, Indonesia, luas wilayah $2.127,25$ $\mathrm{km}^{2}$ dan jumlah penduduk 409.675 jiwa, terletak pada dataran tinggi Tanah Karo, Bukit Barisan Sumatera Utara, menjadi tujuan wisata dari sekitar Tanah Karo maupun pelancong dari negara luar. Objek wisata di Daerah Kabupaten Karo sejumlah kurang lebih 20 objek wisata yang saling berdekatan seperti Bukit Gundaling, Taman Alam Lumbini, Fun Land Mickey Holiday dan tempat lainnya. Prioritas kunjungan daerah wisata sangat perlu ditentukan untuk efisiensi waktu dan biaya dan agar pengunjung dapat menjangkau daerah liburan lainnya yang berada di sekitar Tanah Karo. Sangat memungkinkan dilakukan pengembangan 
sebuah aplikasi sistem informasi yang dapat merekomendasikan prioritas wisata yang harus dikunjungi sehingga tempat-tempat wisata dapat dikunjungi dalam rentang waktu yang efisiensi.

Seorang pengambil keputusan memerlukan alternatif-alternatif jawaban dari sebuah permasalahan. Dalam ilmu komputer dikenal Sistem Pendukung Keputusan (SPK) digunakan untuk menyelesaikan permasalahan berbentuk terstruktur dengan memanfaatkan bahasa komputer merancang sistem. SPK berfungsi mengambil keputusan dalam keadaan terstruktur maupun tidak terstruktur. Pengambilan keputusan untuk permasalahan yang tidak pasti atau belum sepenuhnya diketahui faktor pendukung SPK. Kriteri yang bermacam-macam pada suatu keadaan mempengaruhi pentuan nilai bobot. SPK mendukung penyelesaian permasalahan yang kompleks yang dimulai dari mengidentifikasi permasalahan, jenis kriteria yang dipergunakan juga bobot kriteria yang ditetapkan. Alternatif penyelesaian permasalahan diambil untuk menentukan keputusan yang paling baik untuk seluruh kondisi. Kegiatan pengambil keputusan mencari alternatif penyelesaian dan evaluasi terhadap alternative untuk keputusan yang terbaik.

TOPSIS dipergunakan untuk penentuan solusi ideal positif dan solusi ideal negatif. Solusi ideal positif menghasilkan nilai kriteria yang maksimal dan biaya yang minimal sedangkan solusi ideal negatif bertujuan untuk biaya yang maksimal dan nilai kriteria yang minimal. Prinsip TOPSIS menerapkan alternatif yang terpilih harus mempunyai jarak terdekat dari solusi ideal positif dan jarak terpanjang dari solusi ideal negatif dari sudut pandang geometris dengan menggunakan jarak Euclidean (jarak antara dua titik) untuk menentukan kedekatan relatif dari keadaan alternatif untuk solusi optimal. TOPSIS merupakan metode yang baik dalam pengambilan keputusan untuk mencari alternative dari kriteria. Perbandingan antara jarak relative menjadikan nilai tujuan prioritas alternatif bisa tercapai. Pemodelan TOPSIS menerapkan alternatif yang diambil tidak hanya mempunyai jarak terdekat dari solusi ideal positif, juga meliputi jarak terpanjang dari solusi ideal negatif. Pengkodingan SPK lebih efeisien dalam mengukur kinerja relatif dari data alternatif keputusan kedalam model perhitungan matematis yang sederhana.

Penelitian berjudul Sistem Pendukung Keputusan penentuan lokasi wisata dengan metode TOPSIS menjelaskan data kriteria pembentuk SPK dalam penentuan lokasi wisata dibagi menjadi kriteria menguntungkan dan rugi. Kriteria akan menguntungkan jika kriteria yang mendukung dipilih merupakan data alternatif, sedangkan kriteria akan merugikan jika bersifat sebaliknya. Penelitian berjudul Penerapan Metode Topsis Untuk Sistem Pendukung Keputusan Penentuan Keluarga Miskin pada Desa Panca Karsa II menjelaskan penyelesaian permasalahan optimal TOPSIS diperoleh dengan mengambil kedekatan relatif suatu altenatif terhadap solusi ideal positif. Metode TOPSIS diterapkan pemeringkatan data alternatif-alternatif dari penilaian prioritas nilai kedekatan relatif suatu alternative terhadap solusi ideal positif. Alternatifalternatif yang telah dirangking kemudian dijadikan sebagai sumber bagi penentuan pengambil keputusan untuk menentukan penyelesaian permasalhan terbaik sesuai keinginan.

\section{Metodologi}

Tahapan penentuan permasalahan metode SPK Topsis sebagai berikut:

1. Membentuk normalized decision matrix dengan menghitung matriks ternormalisasi Topsis memerlukan rating pada setiap data kriteria atau data subkriteria yang sudah dinormalisasi.

2. Membentuk weighted normalized decision matrix

Solusi ideal positif A+ dan solusi ideal negatif A- dapat ditentukan berdasarkan rating bobot ternormalisasi (Yij) sebagai menghitung matriks yang terbentuk dari normalisasi bobot. Melakukan perhitungan nilai ternormalisasi bobot dengan mengalikan nilai yang sudah ditentukan pada setiap alternatif dari matrik normalisasi dengan nilai bobot yang ditentukan pengambil keputusan.

$$
y_{i j}=w_{i} r_{i j}
$$

3. Mencari hasil nilai solusi ideal positif dan solusi ideal negatif.

Solusi ideal positif dan solusi ideal negatif dapat dihitung dari bobot yang sudah dinormalisasi dari hasil langkah sebelumnya.

$$
\begin{aligned}
& A^{+}=\left(y 1^{+}, y 2^{+}, y 3^{+}, \ldots, y n^{+}\right) \\
& A^{-}=\left(y 1^{-}, y 2^{-}, y 3^{-}, \ldots, y n^{-}\right)
\end{aligned}
$$

Solusi Ideal negatif (A-) diambil dari pencarian nilai minimal dari nilai ternormalisasi terbobot (yij) jika atributnya adalah atribut keuntungan dan menjadi nilai maksimal dari nilai 
normalisasi terbobot (yij) jika atributnya adalah atribut pembiayaan.

4. Menenetukan jarak antara nilai setiap data alternatif dengan matriks solusi ideal positif dan matriks solusi ideal negatif. Besar jarak antara data alternatif Ai dengan solusi ideal positif. Batas jarak antar alternatif Ai dengan solusi ideal positif $(\mathrm{yj}+)$ yang dinyatakan dalam simbol $\mathrm{Di}+$ diperoleh dari nilai akar dari jumlah nilai tiap alternatif yang diperoleh dengan solusi ideal positif(yi+) dikurangi nilai normalisasi terbobot untuk setiap alternatif (yij) selanjutnya dikali bilangan itu sendiri.

5. Mencari nilai paling dekat setiap data alternatif terhadap solusi ideal (preferensi).

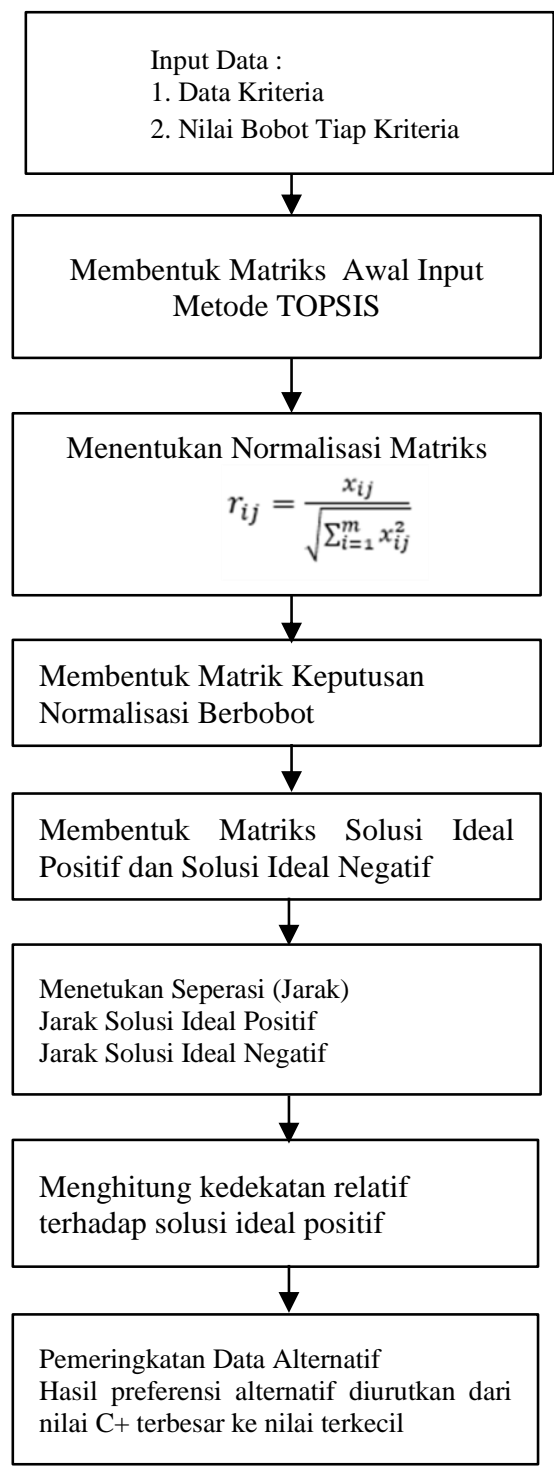

Gambar 1. Tahapan Topsis

\section{Hasil dan Pembahasan}

Konsep dasar (Metode Technique for Order Preference by Similarity to Ideal Solution) TOPSIS menerapkan kalau setiap data kriteria akan menjadi nilai maksimal ataupun nilai minimal. Maka dari itu setiap nilai solusi ideal positif dan solusi ideal negatif dari setiap kriteria yang diperoleh, dan setiap data alternatif akan diperkirakan. Diambil data kriteria penentuan prioritas daerah wisata, melakukan pengumpulan informasi untuk menentukan sumber data yang dibutuhkan dalam rangka mencapai solusi permasalahan penelitian. Solusi maksimal terhadap permasalahan yang terjadi. Pengamatan dilapangan diperoleh melalui wawancara singkat dengan pengunjung objek wisata yang dilakukan di Bukit Kubu Berastagi. Dari hasil pengamatan dari lapangan, dirangkum dan dianalisa diperoleh:

1. Sepuluh objek wisata di Kabupaten karo yang dominan dikunjungi antara lain Bukit Gundaling, Air Terjun Sipiso-piso, Desa Budaya Lingga, Taman Mini Alam Lumbini, Taman Mejuah-Juah, Taman Simalem Resort, Bukit Kubu Berastagi, Lau Sidebuk-debuk, Gundaling Farm Berastagi, Funland Mickey Holiday.

2. Beberapa kriteria yang sering diajukan para wisatawan ketika mengunjungi tempat wisata yaitu jarak dari berastagi, sarana dan fasilitas, akses (transportasi dan infrastruktur), jenis wisata, biaya masuk dan keadaan.

Tabel 1. Data Kriteria

\begin{tabular}{|l|c|}
\hline Kriteria & Kode Kriteria $(\mathrm{C} i)$ \\
\hline Jarak dari Berastagi & $\mathrm{C} 1$ \\
\hline Sarana dan Fasilitas & $\mathrm{C} 2$ \\
\hline Akes & $\mathrm{C} 3$ \\
\hline Jenis Wisata & $\mathrm{C} 4$ \\
\hline Biaya Masuk & $\mathrm{C} 5$ \\
\hline Kuliner & $\mathrm{C} 6$ \\
\hline Jaringan Internet & $\mathrm{C} 7$ \\
\hline
\end{tabular}

Ai meliputi nama tujuan wisata Bukit Gundaling (A1), Air Terjun Sipiso-piso (A2), Desa Budaya Lingga (A3), Taman Mini Alam Lumbini (A4), Taman Mejuah-Juah (A5), Taman Simalem Resort (A6), Bukit Kubu Berastagi (A7), Lau Sidebuk-debuk (A8), Gundaling Farm Berastagi (A9), Funland Mickey Holiday (A10).

Penentuan bobot dari setiap kriteria diperoleh dari pengolahan data hasil wawancara. Bobot kriteria untuk menentukan kriteria yang lebih diutamakan. Semakin besar bobot, maka 
semakin diutamakan. Bobot untuk setiap kriteria penentuan prioritas tujuan tempat wisata, Jarak dari Berastagi (bobot 30\%), Sarana dan Fasilitas (bobot 15\%), Akses (15\%), Jenis Wisata (Bobot 20\%), Biaya Masuk (Bobot 15\%), Kuliner (bobot $5 \%)$, dan Jaringan internet (5\%).

Setiap atribut akan dikonversikan ke dalam bentuk fuzzy sebagai penerapan dari bagian keanggotaan Fuzzy Multi Attribute Decision Making (FMADM). Setiap kriteria di ubah kedalam bentuk anggota.

Perancangan sistem berisi perancangan sistem yang diusulkan, perancangan basis data dan perancangan tampilan. Pembentukan komputasu pengkodingan menggunakan metode waterfall model. Pengembangan aplikasi dirancang menggunakan Microsoft Visual Studio 2010. Use Case diagram SPK Metode TOPSIS, Gambar 2.

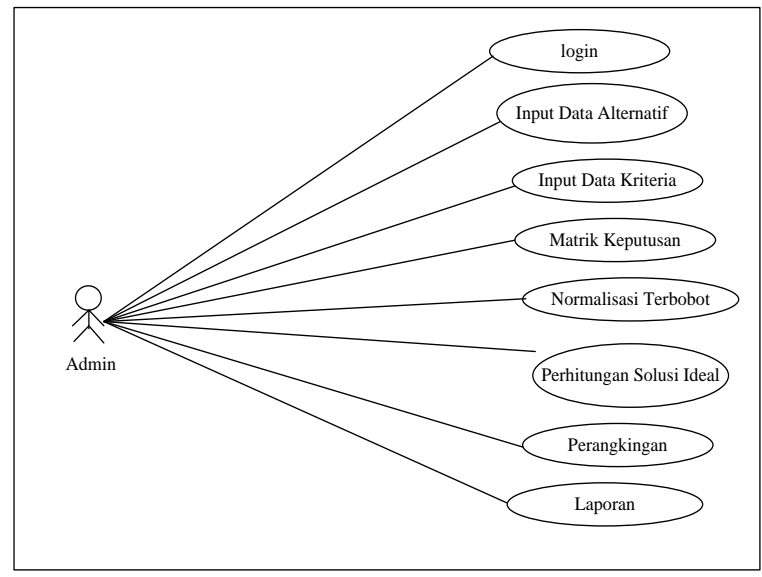

Gambar 2. Use Case Diagram

Langkah-langkah penyelesaian penenetuan prioritas tujuan wisata dengan metode TOPSIS adalah sebagai berikut:

1. Dimulai dengan memasukkan data kriteria sumber data wisata dan bobot setiap nilai kriteria yang telah diubah dalam bentuk nilai fuzzy.

Tabel 2. Hasil Konversi Data

\begin{tabular}{|c|c|c|c|c|c|c|}
\hline \multicolumn{7}{|c|}{ Nilai Fuzzy } \\
\hline C1 & C2 & C3 & C4 & C5 & C6 & C7 \\
\hline 0 & 0 & 0,75 & 0,75 & 0,25 & 0,5 & 0 \\
\hline 0,75 & 0,75 & 0,5 & 0,5 & 0,25 & 0,5 & 0 \\
\hline 0,25 & 0,25 & 0,5 & 0,75 & 0,25 & 0,5 & 0,75 \\
\hline 0 & 0 & 1 & 0,75 & 0,25 & 0,5 & 0,75 \\
\hline 0 & 0 & 0,75 & 0,75 & 0,25 & 0,5 & 0,75 \\
\hline 0,75 & 0,75 & 1 & 0,75 & 1 & 1 & 0,75 \\
\hline 0 & 0 & 0,75 & 0,75 & 0,25 & 0,5 & 0,75 \\
\hline 0 & 0 & 1 & 0,75 & 0,25 & 0,5 & 0,75 \\
\hline 0 & 0 & 1 & 0,75 & 0,25 & 0,5 & 0,75 \\
\hline 0 & 0 & 1 & 0,75 & 1 & 1 & 0,75 \\
\hline
\end{tabular}

2. Menentukan Bobot Referensi untuk kriteria. $\mathrm{Cj}$ $=$ Kriteria yang menjadi acuan dalam penentuan prioritas tujuan wisata daerah.

Tabel 3. Rating Kecocokan

\begin{tabular}{|l|l|l|l|l|l|c|}
\hline C1 & C2 & C3 & C4 & C5 & C6 & C7 \\
\hline 0 & \multicolumn{1}{c|}{0} & 0,75 & 0,75 & 0,25 & 0,5 & 0 \\
\hline 0,75 & 0,75 & 0,5 & 0,5 & 0,25 & 0,5 & 0 \\
\hline 0,25 & 0,25 & 0,5 & 0,75 & 0,25 & 0,5 & 0,75 \\
\hline 0 & 0 & 1 & 0,75 & 0,25 & 0,5 & 0,75 \\
\hline 0 & 0 & 0,75 & 0,75 & 0,25 & 0,5 & 0,75 \\
\hline 0,75 & 0,75 & 1 & 0,75 & 1 & 1 & 0,75 \\
\hline 0 & 0 & 0,75 & 0,75 & 0,25 & 0,5 & 0,75 \\
\hline 0 & 0 & 1 & 0,75 & 0,25 & 0,5 & 0,75 \\
\hline 0 & 0 & 1 & 0,75 & 0,25 & 0,5 & 0,75 \\
\hline 0 & 0 & 1 & 0,75 & 1 & 1 & 0,75 \\
\hline
\end{tabular}

3. Membentuk model matrik keputusan yang sudah dinormalisasi dari setiap kategori dengan simbol $X(i)$. Pembentukan model matrik keputusan berbentuk normalisasi, diperoleh tabel 4.

Tabel 4. Matrik Keputusan

\begin{tabular}{|l|l|l|l|l|l|l|}
\hline C1 & C2 & C3 & C4 & C5 & C6 & C7 \\
\hline 0 & 0 & 0,261 & 0,222 & 0,12 & 0,204 & 0 \\
\hline 0,566 & 0,566 & 0,17 & 0,272 & 0,12 & 0,204 & 0 \\
\hline 0,433 & 0,188 & 0,34 & 0,222 & 0,12 & 0,204 & 0,306 \\
\hline 0,433 & 0 & 0,26 & 0,222 & 0,12 & 0,204 & 0,306 \\
\hline 0,433 & 0 & 0,75 & 0,222 & 0,12 & 0,204 & 0,306 \\
\hline 0,144 & 0,566 & 1 & 0,222 & 0,5 & 0,408 & 0,306 \\
\hline 0,566 & 0,032 & 0,75 & 0,222 & 0,12 & 0,204 & 0,306 \\
\hline 0 & 0,348 & 1 & 0,222 & 0,125 & 0,204 & 0,306 \\
\hline 0 & 0,348 & 1 & 0,222 & 0,12 & 0,204 & 0,306 \\
\hline 0 & 0,348 & 1 & 0,222 & 0,5 & 0,408 & 0,306 \\
\hline
\end{tabular}

4. Menghasilkan model matrik keputusan yang sudah dinormalisasi terbobot (V) dengan elemen-elemen dari R(i) yang telah ditentukan. Rating kinerja atau (X), dan nilai bobot (W) diperoleh dari nilai utama yang menunjukkan hasil perhitungan preferensi absolut dari pengambil keputusan. Penyelesaian permasalahan MADM dilakukan melalui tahapan pemeringkatan untuk memperoleh alternatif paling baik yang diambil dari nilai keseluruhan preferensi yang sudah ditentukan sebelumnya. Pembobotan menunjukkan tingkat kebutuhan relatif setiap data atribut, dianggap sebagai $\mathrm{W}, \mathrm{W}=\{\mathrm{w} 1, \mathrm{w} 2, . ., \mathrm{wn}\}$ diambil Bobot Preferensi $W=[30,10,15,20,15,5,5]$. Hasil tahapan ini diperoleh matriks keputusan ternormalisasi yang sudah terbobot. 
5. Menentukan model matriks Solusi Ideal Positif $\left(\mathrm{A}^{+}\right)$dan Solusi Ideal Negatif $\left(\mathrm{A}^{-}\right)$. Melalui perhitungan solusi ideal positif dan solusi ideal negatif berdasarkan rating bobot yang ternormalisasi $y_{i j}$ dengan rumus persamaan $A^{+}=\left(y_{1}{ }^{+}, y_{2}{ }^{+}, \ldots y_{n}{ }^{+}\right)$

dan $\quad A^{-}=\left(y_{1}{ }^{-}, y_{2}{ }^{-}, \ldots y_{n}{ }^{-}\right)$untuk menentukan $\mathrm{A}+=\mathrm{A}+=(\mathrm{y} 1+, \mathrm{y} 2+, \ldots, \mathrm{yn}+)$.

6. Menentukan seperasi atau jarak alternatif dari solusi ideal positif $\left(\mathrm{S}^{+}\right)$, dengan persamaan rumus $\mathrm{S}_{\mathrm{i}}^{+}=\sqrt{\sum_{j=1}^{n}\left(v_{i j}-v_{j}^{+}\right)^{2}}$

Menentukan seperasi atau jarak alternatif Solusi Ideal Negatif, dengan $\mathrm{S}_{\mathrm{i}}^{-}=$ $\sqrt{\sum_{j=1}^{n}\left(v_{i j}-v_{j}^{-}\right)^{2}}$

7. Menentukan kedekatan relatif alternatif terhadap Solusi Ideal Positif $\left(\mathrm{c}_{\mathrm{i}}^{+}\right), V_{i}=\frac{D_{i}^{-}}{D_{i}^{-}+D_{i}^{+}}$

Tabel 5. Kedekatan Tiap Alternatif

\begin{tabular}{|c|r|r|r|}
\hline$i$ & \multicolumn{1}{|c|}{$\mathrm{S}^{+}$} & \multicolumn{1}{c|}{$\mathrm{S}^{-}$} & $\mathrm{C}^{+}$ \\
\hline 1 & 19,55 & 5,26 & 0,21201 \\
\hline 2 & 8,08 & 18,65 & 0,69771 \\
\hline 3 & 9,3 & 14,4 & 0,60759 \\
\hline 4 & 10,33 & 14,1 & 0,57715 \\
\hline 5 & 11,89 & 16,48 & 0,58089 \\
\hline 6 & 16,31 & 16,34 & 0,50459 \\
\hline 7 & 8,08 & 19,8 & 0,71018 \\
\hline 8 & 19,75 & 13,92 & 0,41342 \\
\hline 9 & 19,75 & 13,92 & 0,41342 \\
\hline 10 & 21,73 & 14,97 & 0,4079 \\
\hline
\end{tabular}

8. Dari hasil perhitungan Nilai Preferensi (V) sebelumnya, dapat ranking dari yang paling besar sampai yang paling kecil; penilaian hasil preferensi dari alternatif yang paling besar adalah data alternatif paling baik dari sumber data dan data alternatif yang diambil, sedangkan data alternatif dengan nilai optimasi paling rendah merupakan paling buruk dari keselurahan data. Dalam urutan dari yang paling besar sampai menuju yang paling kecil, ditentukan hasil tahapan perhitungan yang sudah terurut dari nilai yang paling besar menuju nilai yang paling kecil. Hasil pengurutan ranking besar menuju terkecil, prioritas tujuan wisata, Tabel 6 .

Tabel 6. Hasil Proses Pemeringkatan

\begin{tabular}{|l|c|c|c|}
\hline \multicolumn{1}{|c|}{ Nama Tujuan Wisata } & $\mathrm{S}^{+}$ & $\mathrm{S}^{-}$ & $\mathrm{C}^{+}$ \\
\hline Bukit Kubu Berastagi & 8,08 & 19,8 & 0,71018 \\
\hline Air Terjun Sipiso-piso & 8,08 & 18,65 & 0,69771 \\
\hline
\end{tabular}

\begin{tabular}{|l|c|c|c|}
\hline Desa Budaya Lingga & 9,3 & 14,4 & 0,60759 \\
\hline Taman Mejuah-Juah & 11,89 & 16,48 & 0,58089 \\
\hline Taman Mini Alam Lumbini & 10,33 & 14,1 & 0,57715 \\
\hline Taman Simalem Resort & 16,31 & 16,34 & 0,50459 \\
\hline Gundaling Farm Berastagi & 19,75 & 13,92 & 0,41342 \\
\hline Lau Sidebuk-debuk & 19,75 & 13,92 & 0,41342 \\
\hline Funland Mickey Holiday & 19,55 & 5,26 & 0,21201 \\
\hline Bukit Gundaling & 19,75 & 13,92 & 0,41342 \\
\hline
\end{tabular}

Tahapan untuk menjalankan sistem dalam bentuk tampilan Form disertai penjelasan. Pengguna aplikasi dapat mengunjungi http://localhost/topsis/index.php.

Tampilan form homepage aplikasi berbasis web, Hasil rancangan SPK Menentukan Prioritas Tujuan Wisata Daerah pada Kabupaten Karo dengan Metode TOPSIS terdiri dari:

1. Tampilan Form Login

Pada Form Login, user memasukkan biodata user yaitu input Nama, Alamat dan No. Telepon.

2. Tampilan Form Utama

Form utama menampilkan menu-menu seperti Data Alternatif, Data Kriteria, Nilai Fuzzy, Proses Perhitungan, Hasil, Keputusan dan Logout. Menu Utama tampil setelah registrasi pemakai sistem, merupakan tampilan awal dari sistem aplikasi Gambar 3.

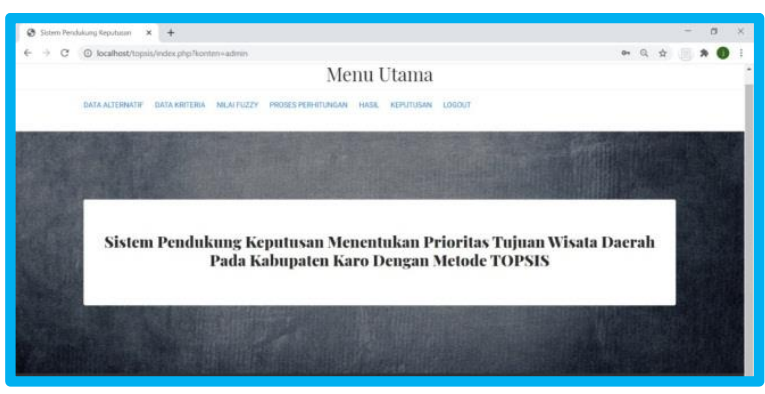

Gambar 3. Tampilan Form Utama

3. Form data alternatif berfungsi untuk memasukkan data daerah tujuan wisata sesuai kebutuhan sistem. Tabel Alternatif menampilkan Nama Tempat Wisata, Lokasi, Jenis Objek, Biaya Masuk, Jarak dari Berastagi. 


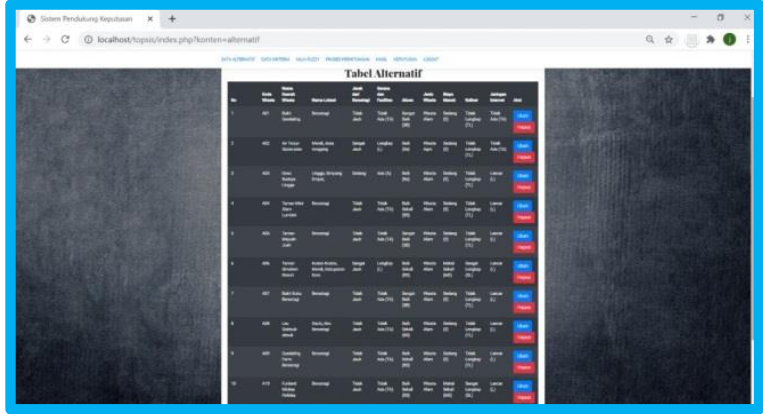

Gambar 4. Form Data Alternatif

4. Form Data Kriteria menampilkan Kode Kriteria, Nama Kriteria dan Bobot Form Kriteria berfungsi untuk mengisi data kriteria dan nilai kriteria penilaian.

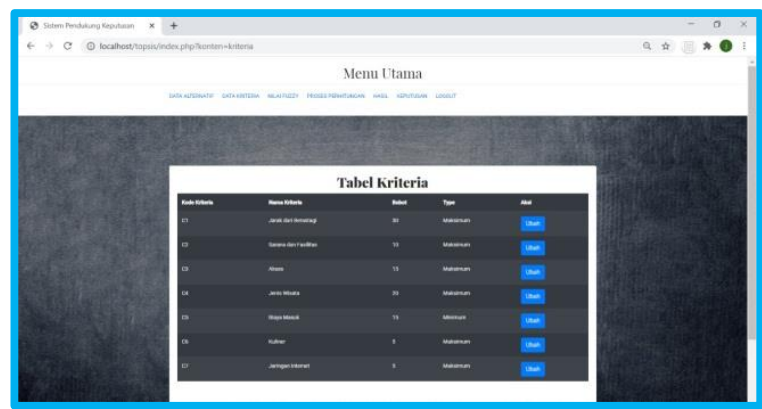

Gambar 5. Form Data Kriteria

5. Setiap data atribut diubah ke dalam bentuk keanggotaam sebagai penerapan FMADM. Setiap kriteria diubah ke dalam bentuk keanggotaan.

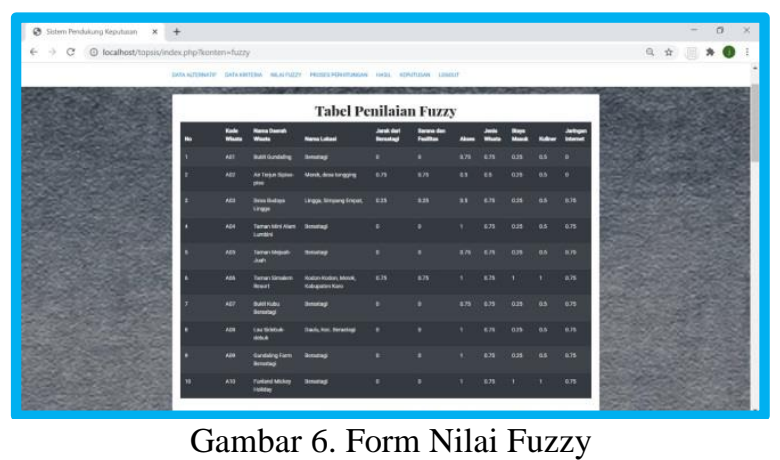

6. Form Menu Proses Perhitungan merupakan Matrik Keputusan yang berfungsi untuk memproses normalisasi $\mathrm{R}$, sehingga diperoleh matrik normalisasi terbobobot. Tabel Matrik Keputusan diperoleh melalui nilai data alternatif dari setiap data kriteria. Pada sistem, user memasukkan Data Alternatif, nilai Data Kriteria dan menentukan Nilai Fuzzy.

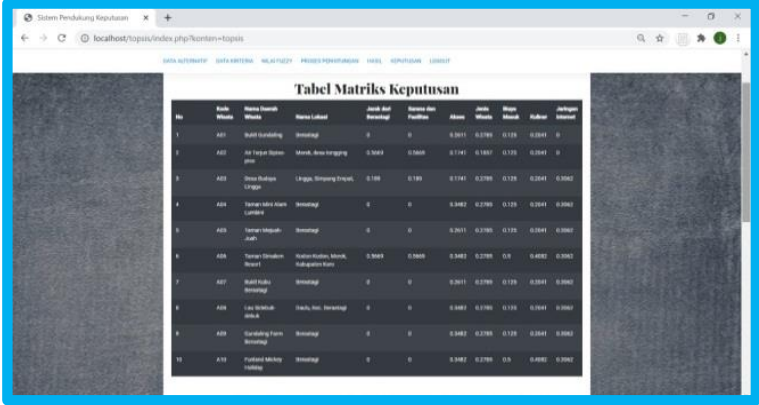

Gambar 7. Form Proses Perhitungan

7. Form Hasil menampilkan Form Kedekatan Tiap Alternatif. Jarak antara Nilai Setiap Alternative dengan Solusi Ideal Positif (D+) dan Jarak antara Nilai Setiap Alternative dengan Solusi Ideal Negative (D-). Dari hasil langkah sebelumnya diperoleh model matrik keputusan yang sudah dinormalisasi, ditampilkan pada Form Kedekatan Tiap Alternatif.

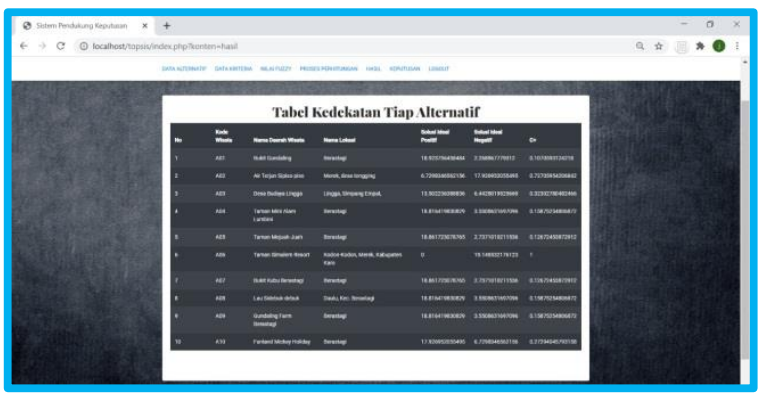

Gambar 8. Kedekatan Tiap Alternatif

8. Tampilan Menu Form Keputusan menampilkan hasil pemeringkatan prioritas tujuan wisata.

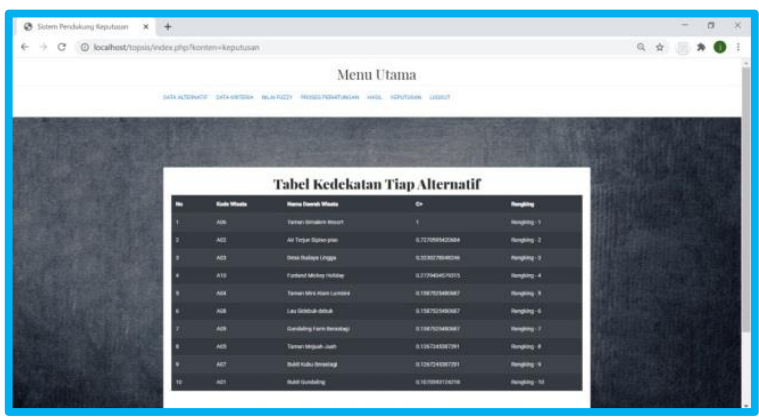

Gambar 9. Hasil Keputusan

Hasil tahapan penentuan Nilai Preferensi (V) yang dirangking diperoleh nilai paling besar sampai paling kecil; hasil perhitungan preferensi dari keseluruhan data paling besar adalah data alternatif paling baik dari sumber data dan menjadi alternatif yang diambil sebagai keputusan paling baik, sedangkan alternatif dengan nilai paling rendah adalah yang paling buruk dari 
sumber data. Dari pengurutan paling besar sampai dengan yang paling kecil, diambil ranking paling atas yaitu Kode Alternatif A06, dengan Nama Alternatif Taman Simalem dengan $\mathrm{C}+=1$.

\section{Kesimpulan}

Penerapan SPK menggunakan Topsis, pada aplikasi menentukan prioritas tujuan wisata dapat disimpulkan:

1. Implementasi metode TOPSIS dapat membantu penentuan Prioritas Tujuan Wisata Daerah pada Kabupaten Karo.

2. Aplikasi Sistem Pendukung Keputusan dengan SPK metode TOPSIS yang dibangun dengan web menghasilkan pengambil keputusan penentuan Prioritas Tujuan Wisata Daerah pada Kabupaten Karo.

3. Aplikasi pendukung keputusan dengan Metode TOPSIS yang dibangun menghasilkan pengambil keputusan dari urutan nilai $\mathrm{C}+$ terbesar sampai nilai terkecil.

\section{Referensi}

Aidah Mus, and Hajra Rasmita. (2018). Sistem Pendukung Keputusan Pemilihan Destinasi Wisata Di Sulawesi Tengah Menggunakan Metode SMART. 7(2): 25-36.

Chaniago, N., \& Sindar, A. (2020). SPK Penilaian Hasil Belajar Siswa Menggunakan Metode TOPSIS. Format : Jurnal Ilmiah Teknik Informatika 9, 41-48.

Darman, R. (2018). Sistem Pendukung Keputusan Pemilihan Imam Shalat Jurnal Edik Informatika. 1, 1-8.

Hasibuan, Abdul Rasid. (2019). Sistem Pendukung Keputusan Pemilihan Objek Wisata Alam Di Kabupaten Padang Lawas Menggunakan Metode Promethee II. Seminar Nasional Teknologi Komputer \& Sains (SAINTEKS): $598-605$.

Hibatullah, M. H., \& Dewi, R. K. (2019). Implementasi Topsis Pada Sistem Rekomendasi Tempat Wisata Pantai Di Sekitar Malang Berbasis Lokasi. 3(4), 3368-3373.

Hozairi, Y., Metode, I., Untuk, T., Faktor, A., \& Efenie, Y. (2019). Keberhasilan Pengelolaan Sekolah Berbasis Web. c.

Kristina, T. (2018). Sistem Pendukung Keputusan Dengan Menggunakan Metode TOPSIS Untuk Pemilihan Lokasi Pendirian Grosir Pulsa. Paradigma, 20(1), 8-12.

Kurniawan, D. E. (2018). Pemilihan Wisata Menggunakan Technique for Order Preference By Similarity To Ideal Solution (Topsis) Dengan Visualisasi Lokasi Objek. Klik Kumpulan Jurnal Ilmu Komputer, 5(1), 75.
Kurnia, Y., Sitio, A. S., \& Sinaga, A. S. (2018). Penilaian Kinerja Guru Menggunakan Metode Topsis. JSAI (Journal Scientific and Applied Informatics), 1(3), 70-75.

Marpaung, M. E., \& Sinaga, A. S. R. (2018). Penilaian Guru Terbaik SMP Tri Sakti Lubuk Pakam Menggunakan Metode Topsis. KomTekInfo, 5(1), 28-35.

Pradani Gayatri S., Ni Ketut, Dwi Putra Githa, and I Putu Arya Dharmaadi. (2018). Sistem Informasi Geografis Rekomendasi Objek Wisata Bali Menggunakan Metode TOPSIS. Jurnal Ilmiah Merpati (Menara Penelitian Akademika Teknologi Informasi) 6(2): 96.

Putra, D. W. T., NoviaSanti, S., Swara, G. Y., \& Yulianti, E. (2020). Metode Topsis Dalam Sistem Pendukung Keputusan Pemilihan Objek Wisata. Jurnal TeknoIf, 8(1), 1.

Sanusi, Sanusi, and Juniana Husna. (2018). Sistem Pengambilan Keputusan Menggunakan Topsis Fuzzy Mcdm Untuk Pemilihan Tempat Wisata Berbasis Web. Jurnal Ilmiah Rekayasa dan Manajemen Sistem Informasi 4(1): 26-35.

Santiary, P. A. W., Ciptayani, P. I., Saptarini, N. G. A. P. H., \& Swardika, I. K. (2018). Metode Topsis Dalam Sistem Pendukung Keputusan Pemilihan Objek Wisata. Jurnal Pengertian Topsis. 5(5), 621-628. 